\title{
The Effectiveness of Direct and Indirect Written Corrective Feedback on English Collocation Competency: A Quasi - Experiment
}

\author{
Abang Fhaeizdhyall \\ Faculty of Language Studies \\ Universiti Malaysia Sarawak (UNIMAS) \\ E-mail: abang385@uitm.edu.my
}

Received: January 20, 2020

Accepted: February 8, 2020 Published: February 10, 2020

doi:10.5296/jsel.v8i1.16434

URL: https://doi.org/10.5296/jsel.v8i1.16434

\begin{abstract}
The primary aim of this study is to investigate the effectiveness of direct and indirect written corrective feedback (WCF) on English collocational competency of high-performing ESL learners. The study also sought to compare possible differences in the effect of two WCF strategies that help the researcher in identifying the appropriate WCF strategy in improving learners' collocational competency in the context of the study. Additionally, retention effect of WCF is also investigated in delayed post-tests. Eighty-eight high-performing ESL learners of a public university participated in the quasi-experimental study of two experimental groups and one control group. A series of test namely pre-test, immediate post-test and delayed post-test was administered to collect the data. The groups are labelled 'Direct group' that received direct WCF treatment $(n=33)$, 'Indirect group' that received indirect WCF $(n=25)$, and 'Control group' that received no treatment $(n=25)$. A set of collocation test that was developed by Gyllstad (2009) was adopted and a pilot test was conducted prior to the actual study. The participants were tested in three point of time (pre-test, immediate post-test, and delayed post-test). The findings indicate that there is a positive effect of direct and indirect WCF strategies on collocational competence. Furthermore, direct WCF has the most effect in improving collocational competency of the participants. Finally, both WCF strategies are proven statistically in retaining their effects as demonstrated in the results of delayed post-test. Suggestion for future studies are also discussed.
\end{abstract}

Keywords: Indirect, Direct, Written Corrective Feedback, English Collocation Competency, High-performing ESL learners 


\section{Introduction}

Lightbown and Spada (2013) defined negative evidence, which is also known as negative and corrective feedback (CF) as the indication to a learner that his or her use of the target language is incorrect. There are several kinds of corrective feedback (CF) as it depends on the nature of the work produce by learners in oral or written form, the context where the corrective feedback is applied, and the kind of errors made by the learners. Oral corrective feedback is generally categorized into two spectrums of implicit and explicit. In the case of implicit oral corrective feedback, the learner is given a hint of his errors in utterances by restating the utterances with rising or falling intonations (Kazemipour, 2014). Ellis, Loewen and Erlam (2006) also indicated that implicit feedback is defined as the type of CF in which there is no overt indicator that incorrect utterances occur thus the CF often given in the form of recasts. A detailed description of implicit CF is mentioned by Long and Long (2007) as a reconstruction of all or part of a learner's immediately preceding utterances in which one or several non-target structures such as grammatical or lexical components are substituted by the corresponding target language forms. Furthermore, throughout the exchange, the focus on the speakers is not on language as an object but meaning. On the other hand, the learners are made aware of the exact errors made by providing them with the correct forms of the target language structures in explicit $\mathrm{CF}$.

Corrective feedback can also be applied in the form of written which is called written corrective feedback (WCF). In the case of WCF, it can be employed either indirectly or directly. Indirect written corrective feedback transpires when the teacher signifies in myriad of ways, for instance, underline or circle, that an error exists but he does not offer the correction or correct structure pertaining to it. This condition entails the learner to deduce or figure out the errors themselves with minimal clues given. English as Second Language (ESL) writing and language acquisition scholars argue that indirect WCF engages learners in guided-learning and problem-solving activities, thus it is preferable among most student writers (Lalande, 1982). This is also supported by Ferris and Roberts (2001) that indirect written feedback in student writers lead to reflection about linguistics forms that promote long-term language acquisition.

Whereas in direct written corrective feedback, the correct form or linguistic structure of the target language is given by writing them next to the errors (Ferris, 2006). This method is advantageous for low-performing learners who are not able to self-correct and clueless about what the correct form might be. According to Bitchener, Young and Cameron (2005), WCF is usually provided by teachers once incorrect structures or grammatical forms are discovered in learners' piece of writing, by providing the correct answers near or above the incorrect ones. Direct WCF is advantageous to low performing learners that it provides specific information about the correct form or linguistic structures (Ellis, 2008). Additionally, direct WCF benefits low proficiency learners in a condition when errors are unsusceptible to self-correction such as word choice and sentence structure and in a situation where the teacher intends to direct students' attention to the patterns of the errors that require self-correction. However, Ellis (2009) argued that direct WCF may not contribute to long-term learning as it requires minimal processing on the part of the learners. Thus, a study 
by Sheen (2007) suggested that direct WCF can be useful in promoting language acquisition of only specific grammatical features.

Research findings by Truscott $(1996,2007)$ have sparked a debate and ongoing discussion about the effectiveness of written corrective feedback in which he claimed that WCF if ineffective or harmful. The centre of the debate focuses on whether WCF is indeed effective or otherwise. His study in fact, was to alert the scholars in the field that was still lacking satisfactory evidence to support the ineffectiveness or effectiveness of CF in improving learners writing accuracy. There were no firm conclusions could be reached upon by the studies, prior to his research with low-quality designs which had also employed poor-quality $\mathrm{CF}$ strategies and teaching methods. However, regardless of existing ambiguity pertaining to the effectiveness of WCF, teachers and educators alike especially in English language classroom were still applying it in their routine lessons. Ferris (1997) argued that WCF is the most common and preferred forms of feedback which prompted scholars to investigate it over the last twenty years, but it is not possible to make a concrete assumption about which options could benefit ESL learners the most. Therefore, it is necessary to discriminate between the effects of various CF methods on different grammatical structures and to select the ones that are producing a desired quality, effectiveness, and usefulness.

There are several studies in the literature that discuss about the effect of WCF on learners' competency of English collocation. A study by Zarei and Mousavi (2016) investigated the effects of three types of feedback on collocational competency of EFL learners. Seventy-eight intermediate students were randomly assigned to three groups that received indirect WCF, direct WCF, and peer feedback. A fill-in-the blanks test, multiple choice, and sentence construction test were used as the primary instruments. The results revealed that indirect group outperformed the other two groups. Furthermore, participants that received direct WCF had the lowest performance. Another study by Jafarpour and Sharifi (2012) investigated the effect of written corrective feedback on collocation competence of EFL learners. Their study revealed that WCF had positive effect on advanced and intermediate groups that received treatments, but not at the elementary level. Wang and Jiang (2015b) argued that the direct situational feedback provided to a group of intermediate EFL outperformed the group that received direct feedback alone in measuring their collocation competency.

Furthermore, there are very few current studies in the literature that investigates the effect of WCF on English collocational knowledge of ESL or EFL learners. Specifically, not much is known regarding the efficacy of direct and indirect WCF on ESL learners' competency of English collocation. Due to lack of studies, very little is known as well on the effect of direct and indirect WCF on high-performing learners' collocational competency in which, prior to this research, a prevalent gap in the literature exists. Thus, this study is geared towards addressing the existing gap, tapping into the grey areas. The findings of this study, along with others by Zarei and Mousavi (2016) and Jafarpour and Sharifi (2012) serve as a statistical evidence in supporting or rejecting the use of WCF as part of strategies in aiding ESL learners' collocational competence especially the high-performing ones. 


\subsection{Statement of Problem}

The study is driven by two prevalent factors as presented in the literature review; lack of consistency in findings of studies focusing on written corrective feedback from the perspectives of cognitive and non-cognitive factors; and very few current studies focusing on the effect of WCF on English collocation in the context of ESL and high-performing learners. This study will provide a finding to address the gap in the literature with regards to the effectiveness of direct and indirect written corrective feedback on English collocation competency. A study by Liu and Brown (2015) that reviews the methodological synthesis of state-of-the-art research on the effectiveness of CF in L2 writing indicates several distinct patterns were discovered for WCF studies which differ from those reported for L2 research. This pattern is predominant in terms of the focus group which favours more on the EFL groups. The researchers indicate further in their study that over half of the analysed studies, which included published studies and theses from online academic databases were conducted in a foreign language context, which contradict the pattern in L2 research as suggested by Plonsky (2013). Additionally, more than half of the studies in their analysis were conducted with intermediate proficiency group, leaving focus on elementary (low-performing) learners and advanced (high-performing) learners under investigated. The current study however focuses on a group of high-performing ESL learners Furthermore, a recent literature search has indicated that English collocation is not the primary subject of research by scholars in Malaysia albeit its contribution towards improving writing accuracy. In detail, little is known about the effect of WCF on English collocation in the context of Malaysian education system.

To study the effect of direct and indirect written corrective feedback on English collocational competence of high-performing learners, the researcher posed the following research question:

Research question 1: What is the effect of providing indirect and direct WCF on the collocational competency of high-performing ESL learners in immediate and delayed post-tests?

Research question 2: Is there any significant difference between the effect of direct WCF and indirect WCF on the collocational competency of high-performing ESL learners?

Research question 3: What is the effect of direct and indirect WCF on collocational competency of high-performing ESL learners over time?

Furthermore, the following null hypotheses were proposed for the above-mentioned questions to be tested:

HO1: Providing indirect and direct written corrective feedback do not have any significant effect on the collocational competency of high-performing ESL learners in immediate and delayed post-tests.

HO2: There is no significant difference between the effect of direct WCF and indirect WCF on the collocational competence of high-performing ESL learners. 
HO3: The effect of direct WCF and indirect WCF on high-performing ESL learners is not retained over time.

\section{Literature Review}

\subsection{Inconclusive Evidence on Written Corrective Feedback}

Past studies in written corrective feedback have yielded different results of its effectiveness in improving learners' writing accuracy. Early studies by Kepner (1991) Robb, Ross, \& Shortreed (1986), Semke (1984), and Sheppard (1992) to investigate the effectiveness of error correction in improving learners' accuracy in writing have failed to discover any statistical differences between the groups receiving WCF and the ones that did not. However, other studies by Chandler (2003), Ferris (1997, 2006), Ferris, Komura, Roberts, \& McKee (2000) claimed to have found positive effects of WCF. Criticism has emerged from these early studies on WCF in which the studies were surrounded by methodological flaws (Wang \& Jiang, 2015). Learning from the flaws of early studies, current studies on WCF are better designed. Thus, most of the studies have produced positive findings (Bitchener, 2008; Bitchener \& Knoch, 2009; Bitchener, Young, \& Cameron, 2005; Ellis, Sheen, Murakami, \& Takashima, 2008; Sheen, Wright, \& Moldawa, 2009). The methodological design of all these studies employed a quasi-experimental design with a non-feedback control group for comparison and the language focus is mainly English grammatical systems. additionally, these studies have also received backlash due to narrow research focus that is only the grammatical aspects of the language. Furthermore, in contrast with the positive findings for WCF, a study by Truscott and Hsu (2008) that compared the texts of writers who received and did not receive WCF and by tracing their accuracy improvement over time, has indicated an opposite finding. Despite the inconclusiveness of its effectiveness, WCF is used in varying forms and degrees in formal classroom instructions (Tan \& Manochphinyo, 2017). Furthermore, Bitchener (2008) argued that the effectiveness of WCF must be measured over time to investigate its retention effect by incorporating delayed pot-test. A study by Bitchener (2008) showed that retention effect was observed in delayed post-test of all treatment groups.

Many researchers have proceeded to investigate the relative effectiveness of various WCF strategies by assuming the practice is beneficial for Second Language (L2) learning despite the call for more empirical studies on the effect of WCF in L2 writing (Wang \& Jiang, 2015). One of the emerging trends that has become the focus of current researchers is the direct-indirect dichotomy which is distinguished by the explicitness of WCF when it is provided. According to Ferris (2003), indirect WCF only indicates that in some ways an error has been made without clear correction provided while direct WCF according to Bitchener (2009) often includes crossing out of an unnecessary word, insertion of a missing word, and written metalinguistic information introducing grammatical rules. An important conundrum thus arises regarding which type of WCF is effective in improving learners' accuracy in L2 writing. A great deal of research has been done over the years with many conflicting results obtained. Ferris (2010) further indicated that the differences in research focus might be the factor that contributed to the conflicting results gained by L2 writing and Second Language 


\section{MInstitute Macrothink $_{\text {Int }}$}

Journal for the Study of English Linguistics

ISSN 2329-7034

2020, Vol. 8, No. 1

Acquisition (SLA) researchers thus indicating that studies on WCF fail to come to any firm conclusions about the merits between direct and indirect WCF.

Over the span of two decades, various studies have been conducted to investigate the effect of direct WCF on learners writing accuracy that produced variable results. Among the earliest ones is a study by Rob, Ross and Shortreed (1986) who conducted a study with 134 Japanese English for Foreign Language (EFL) learners that investigated the effect of direct corrective feedback and other types of indirect corrective feedback strategies. Their study indicated that there were no significant differences observed across the different types of feedback applied in their study. The only significant finding that they discovered was that directing students' attention to surface errors in the group that received direct feedback strategy, consumed less time than the other groups. Additionally, a study by Daneshvar and Rahimi (2014) showed that both experimental groups that received direct and indirect WCF respectively in their study performed better than the control group. The study was conducted to investigate the effectiveness of WCF on grammatical accuracy in learners' writing which also discovered that indirect WCF was able to retain its effect more than what was observed in the direct WCF group.

Another study on the effectiveness of direct feedback showed a different outcome as reported by Chandler (2003) involving 31 English as Second Language (ESL) learners. The researcher was interested to investigate the effects of direct and indirect feedback strategies on learners' revision and discovered that direct feedback strategy was the best for producing precise revisions. It was also discovered that direct feedback was the preferable strategy by the learners because they perceived it as the fastest and easiest way to make revisions. Similarly, the effectiveness of direct corrective feedback was also observed in Bitchener and Knoch (2010) in their study involving 52 ESL learners. A comparison was made among three groups of learners that received three different types of direct feedback with a control group. Their findings indicated that all treatment groups outperformed the control group and no significant difference of effectiveness were observed among the treatment groups that received a variation of direct feedback.

In the case of indirect corrective feedback, it is a strategy of providing feedback by indicating that errors have occurred in a learner's piece of work in terms of grammatical structures, sentence structures, or any linguistic components usually notified by teachers (Ferris \& Roberts, 2001). Furthermore, the indications of errors by teachers are not followed by any detailed descriptions, information or correction which prompted the learners to seek for clarification themselves. The indication of errors is provided in general clues such as an underline, a code, a mark, a circle, or a highlight and the learners are to correct the errors by going through a series self-discovery through external notes or references (Lee, 2008).

Pollard (1990) argued that learners are cognitively challenged through indirect feedback by reflecting upon the general clues on their errors in which the teachers act only as the 'reflective agent'. The teacher is viewed as the reflective agent because he provides the learners with meaningful and appropriate guidance to stimulate learners' cognitive structuring skills from their prior knowledge. In the later stage, learners can relate the clues to the context 
where errors exist, define the area of the error, and eventually correct it by relying on their informed knowledge. Furthermore, Ferris (2003) explained that the indirect corrective feedback strategy improves learners' attention and engagement to form and enable them to be involved in problem-solving activities which are agreed by many scholars as advantageous for long-term learning progress.

Chandler (2003) revealed that current studies of second language acquisition viewed indirect corrective feedback as more effective and useful than direct corrective feedback. Indirect CF enables the learners to be engaged in the correction activity and helps them reflecting upon the errors that they made which also helps the learners in long-term acquisition of the target language structures. Furthermore, various scholars in second language acquisition field agree that indirect $\mathrm{CF}$ is more prospective in helping learners to develop their metalinguistic knowledge and proficiency in the second language (Ferris and Hedgcock, 2005). Additionally, it is also stated by O'Sullivan and Chambers (2006) that indirect CF is more beneficial in encouraging learners' long-term development especially among high-performing or advanced ESL learners.

It can be deduced that there are limited studies over the years to examine the efficacy of direct and indirect WCF which have reported clear and concise evidence on which WCF strategy is more effective in improving ESL learners' proficiency in various linguistic components of the language.

\subsection{English Collocation in the Spotlight of Written Corrective Feedback}

Current studies that are properly designed in terms of their methodological design are focusing more on English grammatical system despite other focus are directed to other elements/systems of the language. One prevalent language system that were not in the spotlight is English collocations. The scope of collocation has to do with the meaning relation between lexical items. Research evidences abound in the literature that show L2 learners have difficulties with putting or arranging words together in a characteristic that is natural as how the native speakers do during speech and writing (Shitu, 2015). Second language learners, in their attempts to achieve competence in the target language often commit errors in language learning. This is due to the nature of language in which there is a kind of natural order that words are arranged or relate to one another in sentences that when a word occurs in a given context, the naturally co-occurring word will come to the mind automatically. Such naturally co-occurring words if paired inappropriately becomes an error in writing. A study focusing on collocation is very significant as it gives insight into helping and leading L2 learners towards achieving some level of accuracy in writing which becomes the second foundation for this study. A study focusing on English collocation is very limited in Malaysian education context. Ang and Tan (2016) conducted a study on preposition related collocation use among British and Malaysian learners and discovered the existence of stark contrast in the writing of both groups where the errors are more apparent among Malaysian learners whereas British learners are free from collocation errors in their study. According to Ang, Hajar, Tan, and Khazriyati (2011), intralingual transfer was found to be the most prominent sources of 
collocational errors in their study. These limited findings indicate that there exists a difficulty among Malaysian L2 learners in terms of using English collocation in their writing.

\section{Methodology}

\subsection{Study Design}

The study employed a quasi-experimental design that consists of two experimental groups and one control group. Quasi-experimental design was selected after reviewing the literature on what is the most applied design of studies on WCF. As indicated in the literature, four early studies (Kepner, 1991; Robb, Ross, \& Shortreed, 1986; Semke, 1984; Sheppard, 1992) intended to investigate the effectiveness of error correction in improving accuracy in writing failed to discover any statistical differences between the treatment groups. Their results, however, were seriously criticized due to methodological problems (Wang and Jiang, 2015a) in which, there were no actual control groups applied in their study. Taking lessons from the criticized studies in the past, current studies are better designed and majority of them have yielded positive results (Bitchener \& Knoch, 2009). Current studies as mentioned by Bitchener and Knoch (2009) employed a quasi-experimental design with a non-feedback control group for comparison and targeted the use of one specific English system. Thus, learning from the flaws and criticism of previous research, this study employed a quasi-experimental design focusing on one specific English system, collocations. Furthermore, a quasi-experimental design is opted because it is not possible to randomize individuals or groups to treatment and control group as this is in line with what have been stated by White and Sabarwal (2014).

\subsection{Participants}

The participants were eighty-three high-performing students of a public university in Kuching, Sarawak. High-performing, which is also categorised as advanced proficiency students, is the focus of this study because the study has one purpose which is to investigate the effect of direct and indirect WCF on English collocational competence of high-performing students. All participants were selected from the faculty of administrative science and policy studies after a series of screening through a prospective group of students for the study. The university offers various programs from 10 faculties in which after a series of screening through previous semester English courses results, it was determined that the students from the Faculty of Administrative Science and Policy Studies performed better than students from other faculties. The faculty was also selected because it was ranked number 1 over other 9 faculties in terms of their performance in the previous semester English course results. The university's policy does not allow the researcher to form randomised selection of groups for the study. Therefore, the experimental groups and control group were selected from seven available groups in the said faculty. The mean score of previous English course results were referred to, and three groups that resembled almost identical mean scores were selected for the study. After the screening process, there are thirty-three students in the 
experimental group that received direct WCF and the group was labelled as Direct WCF. Furthermore, the group that received indirect WCF was labelled as Indirect WCF with twenty-five number of students. Whereas, the group that received no feedback was labelled as Control group with twenty-five students in it.

\subsection{Instruments}

There are very limited tests highly reliable and valid to measure the receptive knowledge of collocations in the literature. However, one that meets the validity and reliability constructs of measuring ESL learners' competency of collocation is COLLMATCH test and COLLEX test that were designed by Gyllstad (2009). The tests were designed by following a rigorous process of defining the construct theoretically, selecting the collocation items from British National Corpus and Vocabulary Levels Test (Nation, 2001), and administering the test to a battery of 300 Swedish ESL learners (See Gyllstad, 2007 for a detailed description of the procedures and results). In the context of this study, COLLMATCH test was adopted as the test instruments to see the effect of different WCF strategies towards the participants' collocation competency. Prior to the actual study, a pilot test was conducted with a group of thirty advanced proficiency students to determine the item facility index in the test (See Carlson and von Davier, 2017 for Item Response Theory). The items that showed high facility index were omitted from the test as it indicates the items were too easy. Additionally, the items that showed low facility index were omitted because they were too difficult. Only items that were close to fifty percent range were retained to be included in the revised version of COLLMATCH test for the actual study. The instruments contain forty collocation items in which the participants must identify the correct combination to be rewarded with one mark. Furthermore, the instruments were distributed in a series of three tests of pre-test, immediate post-test, and delayed post-test over a period of fourteen weeks.

\subsection{Procedures}

The data collection occurred in a duration of fourteen weeks during academic term of 2019 which began on early September until the middle of December. In the first 2-week of their academic term, the researcher, who were assigned to teach English course to the three groups began by reviewing and discussing English collocation lessons. Every group had the opportunity of eight hours over the period of two weeks to do revision on the subject matter. At this stage, no participant was informed that they were involved in a study and had to go through a series of tests. This is to minimise the risk of Hawthorne Effect as the subjects' behaviour may change when they know they are being studied (McCarney, Warner, Iliffe, Van Haselen, Griffin \& Fisher, 2007) which is listed in the drawbacks of experimental study design.

In the third week, a set of pre-test instruments were administered to all three groups. The tests then collected, evaluated by the researcher, and the scores were recorded. The Direct WCF group received direct WCF from the researcher by writing the correct answers on every error 
produced. Additionally, example of a sentence where the correct collocation occur was also written. The Indirect WCF group received indirect WCF by indicating that an error occurred with "X" symbol. No further descriptions or clues pertaining to the errors were given and the participants relied on their effort to work out the errors by any means possible once they received the assessed test. The control group did not receive any treatment, their pre-tests were assessed, scores were recorded, but their pre-test instruments were not returned.

All test instruments belong to the experimental groups were returned in the following week. Upon receiving their pre-test instruments, the participants were given 30 minutes to study the errors. In the case of the control group, their pre-test instruments were not returned. Therefore, no revision was made on the test, but they were assigned with another series of immediate post-test. Whereas, the immediate post-test was administered to both experimental groups after the 30-minute pre-test revision had ended. All immediate post-test instruments belong to the three groups were collected and assessed, and scores were recorded by the researcher.

Exactly ten weeks later, delayed post-test instruments were administered to all the three groups. The purpose of administering delayed post-test is to investigate the effect of WCF over a longer period. According to Bitchener (2008), delayed post-test is integrated in the data collection stages to measure retention over time. Furthermore, the participants were not informed of the delayed post-test to eliminate the possibility of any participants studying and memorising the feedback given in their immediate post-test.

\subsection{Target Structures}

The most widely referenced category of collocation in the literature has been those by Hill (2000) and Lewis (2000) who developed the classification of English collocation into two main groups; lexical collocations and grammatical collocations.

Lexical collocation is used to refer to the relations between two or more content words that appear naturally in a sentence. There are only four out of eight-word classes in English that collocate: adverbs; adjectives; noun; and verb. According to Ridha and Al-Riyahi (2011) and Hsu (2010), a number of classification subtypes have emerged from these four word classes; (1) Verb + noun/P (or prepositional phrase), e.g. set an alarm, break a code, lift a blockade; (2) Adjective + noun, e.g. strong tea, best wishes; (3) Noun + of + noun, e.g. a pride of lions; (4) Verb + adverb, e.g. argue heatedly, appreciate sincerely; (5) Adverb + adjectives, e.g. deeply absorbed, closely related; (6) Noun + verb, e.g. bombs explode, water freezes.

This study focuses only on investigating the effect of WCF on the following two subtypes of collocation: Verb + adverb and noun + verb.

\section{Results}

Before analysing the effects of treatments, a one-way ANOVA was run to compare the mean scores of the three groups in the study. This is to prove that the participants are homogeneous 
in their collocational competency prior to receiving treatments and not receiving treatment in the case of the control group. Table 1 displays the means, standard deviations, and number of participants in every group of the pre-test.

Table 1. Descriptive Statistics of Mean Scores of Pre-test

\begin{tabular}{|c|c|c|c|c|c|c|c|c|}
\hline & \multirow[b]{2}{*}{$\mathrm{N}$} & \multirow[b]{2}{*}{ Mean } & \multirow[b]{2}{*}{ SD } & \multirow[b]{2}{*}{ SE } & \multicolumn{2}{|c|}{$\begin{array}{l}95 \% \text { Confidence } \\
\text { Interval for Mean }\end{array}$} & \multirow[b]{2}{*}{$\begin{array}{l}\text { Minim } \\
\text { um }\end{array}$} & \multirow[b]{2}{*}{ Maximum } \\
\hline & & & & & $\begin{array}{l}\text { Lower } \\
\text { Bound }\end{array}$ & $\begin{array}{l}\text { Upper } \\
\text { Bound }\end{array}$ & & \\
\hline DIRECT & 33 & 20.84 & 4.988 & .86834 & $\begin{array}{l}19.079 \\
7\end{array}$ & $\begin{array}{l}22.617 \\
2\end{array}$ & 12.00 & 30.00 \\
\hline INDIRECT & 25 & 20.56 & 5.315 & $\begin{array}{l}1.0631 \\
4\end{array}$ & $\begin{array}{l}18.365 \\
8\end{array}$ & $\begin{array}{l}22.754 \\
2\end{array}$ & 12.00 & 30.00 \\
\hline CONTROL & 25 & 20.32 & 3.826 & .76533 & $\begin{array}{l}18.740 \\
4\end{array}$ & $\begin{array}{l}21.899 \\
6\end{array}$ & 14.00 & 30.00 \\
\hline TOTAL & 83 & 20.60 & 4.723 & .51852 & $\begin{array}{l}19.570 \\
9\end{array}$ & $\begin{array}{l}21.633 \\
9\end{array}$ & 12.00 & 30.00 \\
\hline
\end{tabular}

The statistical results of one-way ANOVA in table 2 indicates that there were no statistical differences between the mean scores of pre-tests in this study $(\mathrm{F}=0.088, p=0.915>0.05)$. Based on the results, it can be deduced that the three groups were homogeneous in terms of their collocational competency prior to administering the different WCF strategies in later stage of the study.

Table 2. One-way ANOVA Pretest Results

\begin{tabular}{llllll}
\hline & Sum of Squares & $\mathrm{df}$ & Mean Square & $\mathrm{F}$ & Sig. \\
\hline Between & 4.037 & 2 & 2.019 & .088 & .915 \\
$\begin{array}{l}\text { Groups } \\
\text { Within }\end{array}$ & 1825.842 & 80 & 22.823 & & \\
Groups & & & & & \\
Total & 1829.880 & 82 & & & \\
\hline
\end{tabular}

The research question presented in previous section concerned the relative efficacy of direct and indirect WCF. Additionally, three null hypotheses were formulated: (HO1) Providing direct and indirect written corrective feedback does not have any significant effect on the collocational competence of high-performing ESL learners in immediate post-test and delayed post-test; (HO2) there is no significant difference between the effect of direct WCF and indirect WCF on the collocational competence of high-performing ESL learners; and (HO3) the effect of direct WCF and indirect WCF on high-performing ESL learners is not retained over time. Table 3 presents the descriptive statistics for total scores of direct WCF (DIRWE) and indirect WCF (INDWE) groups and the control group (NOWCF). 


\section{Mll Macrothink}

Table 3. Comparison of Mean Scores and Standard Deviation of Pre-test, Immediate Post-test, and Delayed Post-test.

\begin{tabular}{llllllll}
\hline & & Pretest & \multicolumn{3}{c}{ Immediate Posttest } & \multicolumn{2}{c}{ Delayed Posttest } \\
\cline { 3 - 8 } Group & $\mathrm{N}$ & $\mathrm{M}$ & $\mathrm{SD}$ & $\mathrm{M}$ & $\mathrm{SD}$ & $\mathrm{M}$ & $\mathrm{SD}$ \\
\hline DIRWE & 33 & 20.8485 & 4.98824 & 26.1818 & 6.35145 & 25.2424 & 5.04994 \\
INDWE & 25 & 20.5600 & 5.31570 & 22.8000 & 4.55522 & 22.0800 & 5.01597 \\
NOWCF & 25 & 20.3200 & 3.82666 & 20.4400 & 3.48903 & 20.2000 & 3.98957 \\
Total & 83 & 20.6024 & 4.72394 & 23.4337 & 5.59223 & 22.7711 & 5.15687 \\
\hline
\end{tabular}

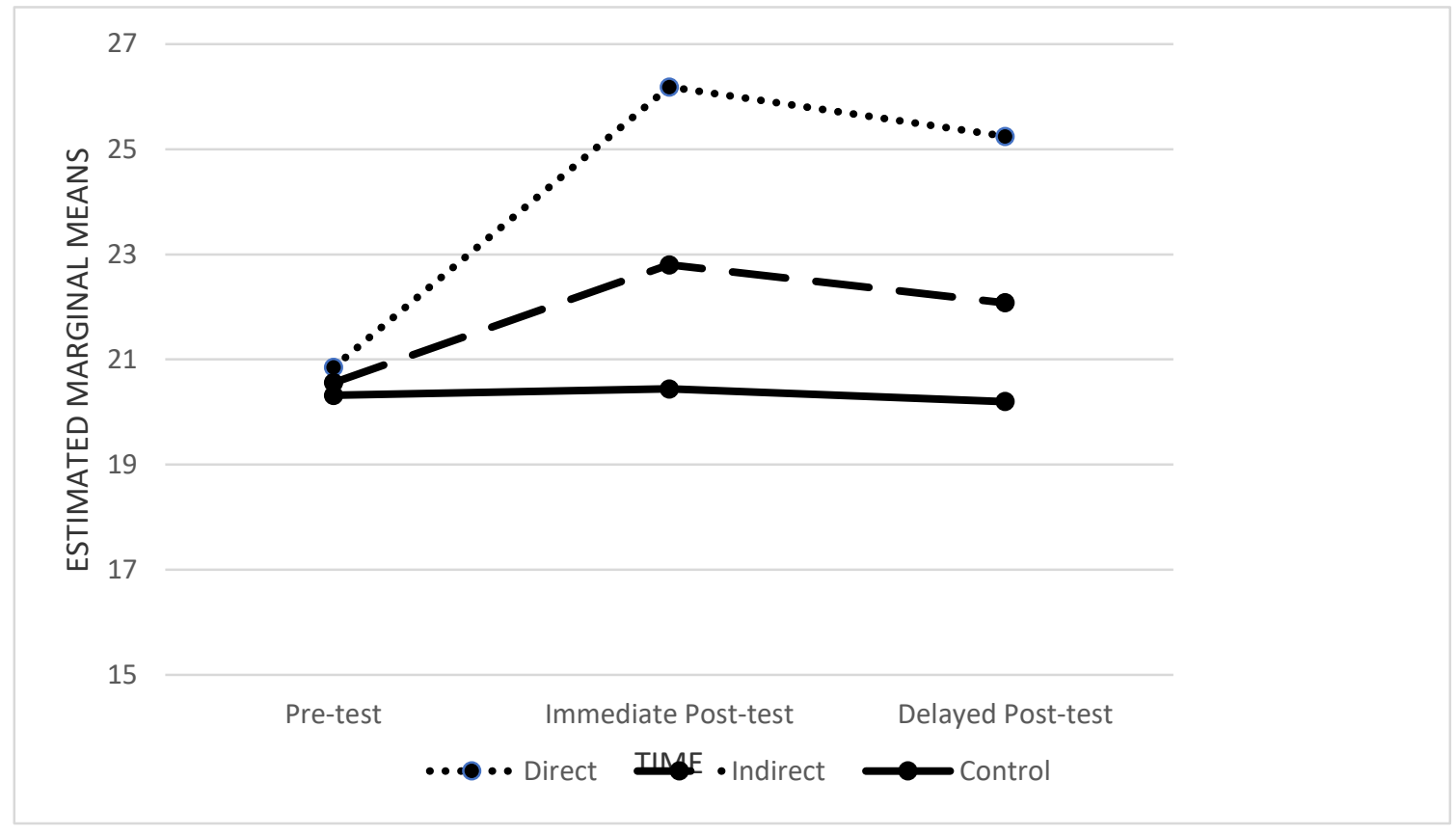

Figure 1. Estimated Marginal Means and Time

The results in table three indicate that there are changes in the means of the treatment groups across three points of time (Pre-test, immediate post-test, and delayed post-test). Thus, it requires additional statistical evidences which will be explained in the following paragraphs.

It should be noted that the mean scores of the control group in three test experienced minute changes over time (pre-test, immediate post-test, and delayed post-test) as illustrated in Figure 1. The crucial analysis thus concerns if there was an interaction between time and treatment. To investigate the interaction, a two-way repeated-measures ANOVA was performed. The dependent variable was identified as total scores while independent variables were time and WCF treatments. In the test of Within Subject Effect, the $p$ value has violated Mauchly's Test of Sphericity ( $p<.05$ ). Thus, the $p$ value of Greenhouse-Geisser was referred to. The results of the analysis presented in table 4 shows that there was a significant interaction between time and the treatments $(\mathrm{F}=12.460, p<0.05$, Partial Eta Square $=0.238)$. 
This indicates that there are significant effects observed over time which also mean that the groups performed differently across all tests.

Table 4. Test of Within Subject Effect

\begin{tabular}{|c|c|c|c|c|c|c|c|}
\hline Source & & $\begin{array}{l}\text { Type III } \\
\text { Sum of } \\
\text { Squares }\end{array}$ & Df & $\begin{array}{l}\text { Mean } \\
\text { Square }\end{array}$ & $\mathrm{F}$ & Sig. & $\begin{array}{l}\text { Partial } \\
\text { Eta } \\
\text { Squared }\end{array}$ \\
\hline TIME & -Geisser & 291.212 & 1.810 & 160.855 & 30.617 & .000 & .277 \\
\hline $\begin{array}{l}\text { TIME* } \\
\text { TREATMENT }\end{array}$ & Greenhouse-Geisser & 237.020 & 3.621 & 65.461 & 12.460 & .000 & .238 \\
\hline
\end{tabular}

A one-way ANOVA was run to determine if there are significant differences between groups in immediate posttest and delayed posttest. The results in table 5 revealed significant difference between-group in all posttests $(\mathrm{F}=9.290, p<.05$ in immediate post-test and $\mathrm{F}=8.408, p<.05$ in delayed post-test). Therefore, the first null hypothesis is rejected.

Table 5. Significant Differences Between Group

\begin{tabular}{lllllll}
\hline & $\begin{array}{l}\text { Sum of } \\
\text { Squares }\end{array}$ & df & $\begin{array}{l}\text { Mean } \\
\text { Square }\end{array}$ & F & Sig. \\
\hline $\begin{array}{l}\text { IMMEDIATE } \\
\text { POST-TEST }\end{array}$ & $\begin{array}{l}\text { Between } \\
\text { Groups }\end{array}$ & 483.316 & 2 & 241.658 & 9.290 & .000 \\
DELAYED POST-TEST & $\begin{array}{l}\text { Between } \\
\text { Groups }\end{array}$ & 378.750 & 2 & 189.375 & 8.408 & .000 \\
& & & & & & \\
\hline
\end{tabular}

The results on Table 5 do not specifically identify which groups differed. Thus, post hoc multiple comparisons were computed in the SPSS to determine where the significant differences appear among the groups with $\alpha$ level at 0.05 .

Table 6. Post Hoc Test of Immediate Post-Test

\begin{tabular}{|c|c|c|c|c|c|}
\hline Dependent & (I) & (J) & Mean & Std. & Sig. \\
\hline Variable & TREATMENT & TREATMENT & $\begin{array}{l}\text { Difference } \\
(\mathrm{I}-\mathrm{J})\end{array}$ & Error & \\
\hline IMMEDIATE & DIRECT & INDIRECT & $3.38182 *$ & 1.35234 & .014 \\
\hline \multirow[t]{5}{*}{ POST_TEST } & & CONTROL & $5.74182 *$ & 1.35234 & .000 \\
\hline & INDIRECT & DIRECT & $-3.38182^{*}$ & 1.35234 & .014 \\
\hline & & CONTROL & 2.36000 & 1.44259 & .106 \\
\hline & CONTROL & DIRECT & $-5.74182^{*}$ & 1.35234 & .000 \\
\hline & & INDIRECT & -2.36000 & 1.44259 & .106 \\
\hline
\end{tabular}


Table 7. Post Hoc Test of Delayed Post-Test

\begin{tabular}{|c|c|c|c|c|c|}
\hline Dependent & (I) & $(\mathrm{J})$ & Mean & Std. & Sig. \\
\hline Variable & TREATMENT & TREATMENT & $\begin{array}{l}\text { Difference } \\
(\mathrm{I}-\mathrm{J})\end{array}$ & Error & \\
\hline DELAYED & DIRECT & INDIRECT & $3.16242 *$ & 1.25837 & .014 \\
\hline \multirow[t]{5}{*}{ POST-TEST } & & CONTROL & $5.04242 *$ & 1.25837 & .000 \\
\hline & INDIRECT & DIRECT & $-3.16242 *$ & 1.25837 & .014 \\
\hline & & CONTROL & 1.88000 & 1.34235 & .165 \\
\hline & CONTROL & DIRECT & $-5.04242 *$ & 1.25837 & .000 \\
\hline & & INDIRECT & -1.88000 & 1.34235 & .165 \\
\hline
\end{tabular}

The results in tables 6 and 7 revealed that in both immediate post-test and delayed post-test, the group that received direct WCF performed better than the indirect WCF group and control group. However, no significant difference was observed between the indirect WCF group and control group. It is also noted that the direct WCF group outperformed the indirect group and control group in both immediate post-test and delayed post-test. Thus, the second null hypothesis is rejected. The statistically significant differences that emerged from this analysis is summarized in table 8 .

Table 8. Summary of Statistically Significant Group Differences

\begin{tabular}{|l|l|}
\hline Time & Total test scores \\
\hline Immediate post-test & $\begin{array}{l}\text { Direct WCF }>\text { Indirect WCF* } \\
\text { Direct WCF }>\text { Control* }\end{array}$ \\
\hline Delayed post-test & $\begin{array}{l}\text { Direct WCF }>\text { Indirect WCF* } \\
\text { Direct WCF }>\text { Control* }\end{array}$ \\
\hline
\end{tabular}

Note. The symbol $>$ denotes 'better than' and the asterisk indicates that $p<0.05$

To test the long-term effect of direct WCF strategies on collocation competency of high-performing ESL in the study, another series of repeated measures ANOVA was run. Table 8 shows the results of the analysis which indicate that there is a significant difference in the mean scores between pre-test and immediate post-test $(p<.05)$. Similarly, significant different is also observed between pre-test and delayed post-test $(p<.05)$. However, no significant different is observed between immediate post-test and delayed post-test $(p>.05)$. Thus, collocational competency of the participants, after being exposed to direct WCF, is retained in delayed post-test. 
Table 9. The Effect of Time in Direct WCF Group's Total Scores

\begin{tabular}{lllll}
\hline (I) TIME & $(\mathrm{J})$ TIME & $\begin{array}{l}\text { Mean } \\
\text { Difference (I-J) }\end{array}$ & Std. Error & Sig. \\
\hline 1 & 2 & $-5.333^{*}$ & .757 & .000 \\
& 3 & $-4.394^{*}$ & .640 & .000 \\
2 & 1 & $5.333^{*}$ & .757 & .000 \\
& 3 & .939 & .685 & .540 \\
3 & 1 & $4.394^{*}$ & .640 & .000 \\
& 2 & -.939 & .685 & .540 \\
\hline
\end{tabular}

To test the long-term effect of indirect WCF strategies on collocational competency of high-performing ESL in the study, another series of repeated measures ANOVA was run. Table 9 shows the results of the analysis which indicate that there is a significant difference in the mean scores between pre-test and immediate post-test $(p<.05)$. Similarly, significant different is also observed between pre-test and delayed post-test $(p<.05)$. However, no significant difference is observed between immediate post-test and delayed post-test $(p>.05)$. Thus, collocational competency of the participants, after being exposed to indirect WCF, is retained in delayed post-test. These two evidences are enough to reject the third null hypothesis.

Table 10. The Effect of Time in Indirect WCF Group's Total Scores

\begin{tabular}{lllll}
\hline (I) TIME & $(\mathrm{J})$ TIME & $\begin{array}{l}\text { Mean } \\
\text { Difference (I-J) }\end{array}$ & Std. Error & Sig. \\
\hline 1 & 2 & $-2.240^{*}$ & .794 & .009 \\
& 3 & $-1.520^{*}$ & .530 & .008 \\
2 & 1 & $2.240^{*}$ & .794 & .009 \\
& 3 & .720 & .453 & .125 \\
3 & 1 & $1.520^{*}$ & .530 & .008 \\
& 2 & -.720 & .453 & .125 \\
\hline
\end{tabular}

Finally, the post hoc analysis on the control group did not show any significant different between pre-test and immediate post-test $(p>.05)$, pretest and delayed post-test $(p>.05)$, and immediate post-test and delayed post-test $(p>.05)$.

\section{Conclusion}

The purpose of the current study was to investigate the effect of direct and indirect written corrective feedback (WCF) on collocational competency of high-performing ESL learners. Additionally, three research questions were formulated to guide the researcher and three hypotheses were developed to be tested. 
The first hypothesis concerns the necessity to provide any kind of corrective feedback (CF), in the case of the study, direct and indirect WCF, which do not have any significant effect on the collocational competency of high-performing ESL learners in immediate post-test and delayed post-test. This hypothesis was derived from the literature that shows inconsistency of the effectiveness of WCF in improving learners' proficiency and accuracy in writing (Chandler, 2003; Ferris, 1997\& 2006; Ferris, et. al., 2000; Bitchener, 2008; Bitchener \& Knoch, 2009; Bitchener, et. al., 2005; Ellis, et. al., 2008; Sheen, et. al., 2009; Truscott and Hsu, 2008) and collocational competency (Zarei \& Mousavi, 2016; Jafarpour \& Sharifi, 2012; Wang \& Jiang, 2015b). The results of the analysis presented in previous section show that there was a significant interaction between time and the treatments. This indicates that there are significant effects observed over time which also mean that the groups performed differently across all tests. The results also revealed significant differences between-group in all post-tests. Thus, the first null hypothesis is rejected because the scores were different across all tests which is also observed in all groups. The findings in this study is in line with studies by Chandler (2003), Ferris (1997, 2006), Ferris, Komura, Roberts, and McKee (2000) who claimed to have found positive effects of WCF.

The line of separation has appeared in the literature that divides the effectiveness of direct and indirect WCF on ESL learners' proficiency in the language. Prior to the commission of this research, there was very little current evidence to support which WCF strategy has the most effect on learners' competency in English collocation. The findings of this study rejected the second null hypothesis and concluded that there is a significant difference between the effect of direct WCF and indirect WCF on collocational competency of high-performing ESL learners. The findings summarise group differences in both post-tests and indicates that direct WCF group performed better than indirect WCF group. This finding refutes a finding by Zarei and Mousavi (2016) that indirect WCF group outperformed the direct WCF group. it is noteworthy that while Zarei and Mousavi (2016) investigated the effect on EFL learners, this study however focused on ESL learners. Additionally, no significant difference was observed between indirect WCF group and the control group in all post-tests. These findings offer a suggestion that indirect WCF is more effective in improving ESL learners' competency in English collocation in the context of the study.

The final null hypothesis of this study concerned over the retention effect of both WCF strategies. To investigate the retention effect, delayed post-test was administered ten weeks after immediate post-test. The results of analysis reject null hypothesis because no significant different was observed between immediate post-test and delayed post-test in both direct and indirect WCF groups. This indicates that the effect of direct and indirect WCF was retained over a period of ten-week. The findings corroborate Bitchener (2008) that the retention effect of WCF were observed in delayed post-tests of all treatment groups.

The findings of this study are substantial in highlighting the efficacy of direct and indirect WCF on collocational competency of high-performing ESL learners. It should be noted that, 
this study differs in terms of the language focus as much research has been devoted in the literature was aimed at investigating the effect on English grammatical system whereas collocational competency is the focus here. The study fills the gap in the literature by statistically proving that there is a positive effect of direct and indirect WCF strategies on collocational competency. Furthermore, direct WCF as presented in the findings has the most effect in improving collocation competence as demonstrated in all post-test results. Finally, both WCF strategies are proven statistically in retaining their effects as demonstrated in the results of delayed post-test.

This study has shifted the focus of future researchers as there are many unknown areas of WCF effect on English collocational competency. Therefore, various other WCF strategies should be integrated in future studies to investigate their effect on collocational competency as this study has only applied direct and indirect WCF. Furthermore, it is suggested that this study should be replicated to see the effect on low-performing or low proficiency ESL learners as the participants in this study were high-performing ESL learners. Future studies may be driven to identify the external factors or variables that have caused the retention effect despite an effort was made to control it in the period of ten weeks before the delayed post-test was administered. Additionally, qualitative instruments should be integrated in future studies to investigate qualitative findings that might explain details beyond the limit of quantitative instruments.

\section{References}

Ang, L. H., \& Tan, K. H. (2016). Preposition-Related Collocation use among British and Malaysian Learners: A Corpus Analysis. Pertanika Journal of Social Sciences and Humanities, 24, 145-156.

Ang, L. H., Hajar, A. R., Tan, K. H., \& Khazriyati, S. (2011). Collocations in Malaysian English learners' writing: A corpus-based error analysis. 3L: The Southeast Asian Journal of English Language Studies, 17, 31-44.

Bitchener, J. (2008). Evidence in support of written corrective feedback. Journal of second language writing, 17(2), 102-118.

Bitchener, J. (2009). Measuring the effectiveness of written corrective feedback: Aresponse to "Overgeneralization from a narrow focus: A response to Bitchener (2008)". Journal of Second Language Writing, 18, 276-279. http://dx.doi.org/10.1016/j.jslw.2009.06.001

Bitchener, J., \& Knoch, U. (2009). The relative effectiveness of different types of direct written corrective feedback. System, 37, 322-329.

Bitchener, J., Young, S., \& Cameron, D. (2005). The effect of different types of corrective feedback on ESL student writing. Journal of Second Language Writing, 14, 191-205. 
Carlson, J. E., \& von Davier, M. (2017). Item Response Theory. In Bennett R. and von Davier M. (Eds.), Advancing Human Assessment: The Methodological, Psychological and Policy Contributions of ETS (pp. 133-178). New York, NY: Springer.

Chandler, J. (2003). The efficacy of various kinds of error feedback for improvement in the accuracy and fluency of L2 student writing. Journal of Second Language Writing, 12, 267-269.

Daneshvar, E., \& Rahimi, A. (2014). Written Corrective Feedback and Teaching Grammar. Procedia - Social and Behavioral Sciences, 136, 217-221. https://doi.org/10.1016/j.sbspro.2014.05.317

Ellis, R. (2008). A typology of written corrective feedback types. ELT Journal, 28(2), 97-107.

Ellis, R. (2009). Corrective feedback and teacher development. L2 Journal, 3-18.

Ellis, R., Loewen, S., \& Erlam, R. (2006). Implicit and explicit corrective feedback and the acquisition of L2 grammar. Studies in second language acquisition, 28(2), 339-368.

Ellis, R., Sheen, Y., Murakami, M., \& Takashima, H. (2008). The effects of focused and unfocused written corrective feedback in an English as a foreign language context. System, 36(3), 353-371.

Ferris, D. R. (1997). The influence of teacher commentary on student revision. Tesol Quarterly, 31(2), 315-339.

Ferris, D. R. (2003). Response to student writing: Implications for second language students. New York, NY: Routledge.

Ferris, D. R. (2006). Does error feedback help student writers? New evidence on the short-and long-term effects of written error correction. In K. Hyland \& F. Hyland (Eds.), Feedback in second language writing: Contexts and issues (pp. 81-104). Cambridge, UK: Cambridge University Press

Ferris, D. R. (2010). Second language writing research and written corrective feedback in SLA.Studies in Second Language Acquisition, 32, 181-201. https://doi.org/10.1017/S0272263109990490

Ferris, D. R., Chaney, S. J., Komura, K., Roberts, B. J., \& McKee, S. (2000, March). Perspectives, problems, and practices in treating written error. In Colloquium presented at International TESOL Convention, Vancouver, BC.

Ferris, D.R., \& Roberts, B. (2001). Error feedback in L2 writing classes: How explicit does it need to be? Journal of Second Language Writing, 10, 161-184. 
Ferris, D. R., \& Hedgcock, J. (2005). Teaching ESL composition: Purpose, process, and practice. Mahwah, NJ: Lawrence Erlbaum.

Ferris, D., \& Roberts, B. (2001). Error feedback in L2 writing classes. How explicit does it need to be? Journal of Second Language Writing. 10(3), 161-184.

Gyllstad H. (2009) Designing and Evaluating Tests of Receptive Collocation Knowledge: COLLEX and COLLMATCH. In: Barfield A., Gyllstad H. (Eds.), Researching Collocations in Another Language (pp. 153-170). Palgrave Macmillan, London.

Hill, J. (2000). 'Re-visiting priorities: From grammatical failure to collocation success' in. M. Lewis (Ed.), Teaching Collocation: Further development in the lexical approach (pg. 47-69). London, England: Commercial Color Press Plc.

Hsu, J. Y. (2010). The effects of collocation instruction on the reading comprehension and vocabulary learning of Taiwanese college English majors. Asian EFL journal, 12(1), 47-87.

Jafarpour, A. A., \& Sharifi, A. (2012). The effect of error correction feedback on the collocation competence of Iranian EFL learners. Teaching English with Technology, 12(3), 3-17.

Kazemipour, S. (2014). Comparing the outcomes of two types of corrective feedback on EFL classes' final exam. Procedia-Social and Behavioral Sciences, 98, 876-881.

Kepner, C. G. (1991). An experiment in the relationship of types of written feedback to the development of second-language writing skills. The modern language journal, 75(3), 305-313.

Lalande, J. F. (1982). Reducing composition errors: an experiment. Modern Language Journal 66, 140-149.

Lee, I. (2008). Understanding teachers' written feedback practices in Hong Kong secondary classrooms. Journal of Second Language Writing, 17, 69-85. 19(3), 37-66.

Lewis, M. (2000). Teaching collocation: Further development in the lexical approach. London, England: Commercial Color Press.

Lightbown, P. M., \& Spada, N. (2013). How languages are learned 4th edition-Oxford Handbooks for Language Teachers. Oxford, UK: Oxford university press.

Liu, Q., \& Brown, D. (2015). Methodological synthesis of research on the effectiveness of corrective feedback in L2 writing. Journal of Second Language Writing, 30, 66-81.

Long, M., \& Long, M. (2007). Problems in Second Language Acquisition. New York: Routledge. https://doi.org/10.4324/9781315089447 


\section{Macrothink}

Journal for the Study of English Linguistics

ISSN 2329-7034

2020, Vol. 8, No. 1

McCarney, R., Warner, J., Iliffe, S., Van Haselen, R., Griffin, M., \& Fisher, P. (2007). The Hawthorne Effect: a randomised, controlled trial. BMC medical research methodology, 7(1), 30.

Nation, I. S. (2001). Learning vocabulary in another language. Ernst Klett Sprachen.

O'Sullivan, I., \& Chambers, A. (2006). Learners' writing skills in French Corpus consultation and learner evaluation. Journal of Second Language Writing, 15, 49-68.

Plonsky, L. (2013). Study quality in SLA: An assessment of designs, analyses, and reporting practices in quantitative L2research. Studies in Second Language Acquisition, 35, 655-687. http://dx.doi.org/10.1017/S0272263113000399

Pollard, A. (1990). Towards a sociology of learning in primary schools. British Journal of Sociology of Education, 11(3), 241-256.

Rob, T., Ross, S., \& Shortreed, I. (1986). Salience of feedback on error and its effect on EFL writing quality. TESOL Quarterly, 20(1), 83-95.

Semke, H. D. (1984). Effects of the red pen. Foreign language annals, 17(3), 195-202.

Sheen, Y. (2007). The effect of focused written corrective feedback and language aptitude on ESL learners' acquisition of articles. TESOL Quarterly 41, 255-283.

Sheen, Y., Wright, D., \& Moldawa, A. (2009). Differential effects of focused and unfocused written correction on the accurate use of grammatical forms by adult ESL learners. System, 37(4), 556-569.

Sheppard, K. (1992). Two feedback types: Do they make a difference? RELC Journal, 23, 103-110.

Shin, D., \& Nation, P. (2007). Beyond single words: The most frequent collocations in spoken English. ELT journal, 62(4), 339-348.

Shitu, F. (2015). Collocation errors in English as second language (ESL) essay writing. International Journal of Social, Behavioral, Educational, Economic, Business and Industrial Engineering, 9(9), 3176-3183.

Tan, K. E., \& Manochphinyo, A. (2017). Improving Grammatical Accuracy in Thai Learners' Writing: Comparing Direct and Indirect Written Corrective Feedback. The Journal of Asia TEFL, 14(3), 430-442.

Truscott, J. (1996). The case against grammar correction in L2 writing classes. Language learning, 46(2), 327-369.

Truscott, J. (2007). The effect of error correction on learners' ability to write accurately. Journal of second language Writing, 16(4), 255-272. 


\section{Macrothink}

Journal for the Study of English Linguistics

ISSN 2329-7034 2020, Vol. 8, No. 1

Truscott, J., \& Hsu A. Y. (2008). Error correction, revision, and learning. Journal of Second Language Writing, 17, 292-305.

Wang, T., \& Jiang, L. (2015a). Studies on written corrective feedback: theoretical perspectives, empirical evidence, and future directions. English Language Teaching, 8(1), 110-120.

Wang, T., \& Jiang, L. (2015b). The Effects of Written Corrective Feedback on Chinese EFL Learners' Acquisition of English Collocations. Chinese Journal of Applied Linguistics, 38(3). http://dx.doi.org/10.1515/cjal-2015-0020

White, H., \& Sabarwal, S. (2014). Quasi-experimental design and methods. Methodological Briefs: Impact Evaluation, 8, 1-16.

Zarei, A. A., \& Mousavi, M. (2016). The Effects of Feedback Types on Learners' Recognition of Lexical Collocations. International Journal of Applied Linguistics and English Literature, 5(2), 150-158. http://dx.doi.org/10.7575/aiac.ijalel.v.5n.2p.150

\section{Copyright Disclaimer}

Copyright for this article is retained by the author(s), with first publication rights granted to the journal.

This is an open-access article distributed under the terms and conditions of the Creative Commons Attribution license (http://creativecommons.org/licenses/by/3.0/). 